\title{
Kebijakan Vaksinasi COVID-19: Pendekatan Pemodelan Matematika Dinamis Pada Efektivitas Dan Dampak Vaksin Di Indonesia
}

\author{
Narila Mutia Nasir ${ }^{1}$, Ibnu Susanto Joyosemito ${ }^{2, *}$, Baequni Boerman ${ }^{1}$, Ismaniah ${ }^{2}$ \\ ${ }^{1}$ Fakultas IImu Kesehatan; UIN Syarif Hidayatullah Jakarta; JI. Kertamukti No. 5, Pisangan, \\ Ciputat, Tangerang Selatan, Banten 15419, Telp: (021) 74716718; e-mail: \\ narilamutia@uinjkt.ac.id; baequni@uinjkt.ac.id \\ ${ }^{2}$ Fakultas Teknik; Universitas Bhayangkara Jakarta Raya; Jl. Raya Perjuangan, Marga Mulya, \\ Bekasi Utara, Kota Bekasi, Jawa Barat 17121, Telp: (021) 88955882, 889955883; e-mail: \\ ibnu.susanto@dsn.ubharajaya.ac.id; ismaniah@ubharajaya.ac.id \\ * Korespondensi: e-mail: ibnu.susanto@dsn.ubharajaya.ac.id
}

\begin{abstract}
The COVID-19 vaccination program in Indonesia that started on January 13, 2021 is expected to accelerate the herd immunity that will impact on reducing the infected cases. The World Health Organization (WHO) explained that vaccine performance can be measured through vaccine efficacy, effectiveness, and impact. This community service activity aims to provide inputs for policy implementation on COVID-19 vaccination strategy to the government by conducting predictive analysis using a dynamic mathematical modeling to determine the effectiveness and impact of vaccination at the community level. Five types of vaccines were analyzed, namely AstraZeneca, Moderna, Pfizer, Sinopharm and Sinovac. Two basic model scenarios of with and without the vaccination policy implementation were simulated. The model demonstrated that the policy noticeably reduces the number of COVID-19 cases. The main finding demonstrated by the model is that the effectiveness of the vaccine after it is immunized into the community is affected by its efficacy, but the efficacy of various vaccines type does not influence significantly to the vaccine impact on community. Thus, it is recommended that the government ensures the availability of any type of vaccines to accelerate the vaccination program and encourage community participation to be vaccinated to achieve the target goal. Furthermore, since the impact of vaccine on the community is not only determined by its efficacy, the government have to do persistent health education and drive community engagement to adhere with the COVID-19 health protocol.
\end{abstract}

Keywords: COVID-19, Dynamics Modeling, High Leverage Policy, Vaccine Effectiveness, Vaccine Impact

\begin{abstract}
Abstrak
Program vaksinasi COVID-19 di Indonesia yang mulai dilaksanakan pada tanggal 13 Januari 2021 diharapkan dapat mempercepat terjadinya kekebalan kelompok (herd immunity) yang nantinya berdampak pada penurunan jumlah kasus yang terinfeksi. Organisasi Kesehatan Dunia (WHO) memaparkan bahwa kinerja vaksin dapat dilihat dari tiga pengukuran yaitu melalui efikasi, efektivitas, dan dampak vaksin. Kegiatan pengabdian kepada masyarakat ini bertujuan untuk memberikan masukan kepada pemerintah dalam mengimplementasikan strategi vaksinasi COVID-19 dengan menyediakan analisis prediksi menggunakan pemodelan matematika dinamis untuk mengetahui efektivitas dan dampak vaksinasi pada tingkat masyarakat. Lima jenis vaksin yang dianalisis adalah AstraZeneca, Moderna, Pfizer, Sinopharm dan Sinovac. Dua skenario dasar pemodelan yaitu dengan dan tanpa intervensi kebijakan vaksinasi disimulasikan. Hasil keluaran model menunjukkan kebijakan vaksinasi memberikan
\end{abstract}


dampak dalam penurunan jumlah kasus COVID-19. Temuan utama yang didemonstrasikan oleh model adalah efektivitas vaksin setelah diimunisasikan ke masyarakat dipengaruhi oleh efikasinya, tetapi efikasi antar jenis vaksin tidak terlalu berpengaruh terhadap dampak vaksin di masyarakat. Oleh karena itu disarankan agar pemerintah menjamin ketersediaan vaksin apa pun jenisnya untuk mengakselerasi proses vaksinasi ke masyarakat dan mendorong partisipasi masyarakat untuk divaksin sehingga target yang sudah ditetapkan tercapai. Selanjutnya, mengingat bahwa dampak vaksin di masyarakat bukan hanya ditentukan oleh efikasinya, maka pemerintah harus terus melakukan upaya edukasi dan mendorong pelibatan masyarakat secara aktif untuk patuh menerapkan protokol kesehatan COVID-19.

Kata kunci: COVID-19, Pemodelan Dinamis, Kebijakan Berpengaruh Tinggi, Efektivitas Vaksin, Dampak Vaksin

\section{Pendahuluan}

Pandemi Coronavirus Disease 2019 (COVID-19) belum berakhir dan masih menjadi ancaman global. Berdasarkan data World Health Organization (WHO), total kasus positif yang terkonfirmasi tepat satu tahun pandemi tanggal 11 Maret 2021 adalah 117.788 .562 kasus (World Health Organization, 2021a). Keadaan itu membuat sejumlah negara termasuk Indonesia terus berjuang untuk menghentikan penyebaran COVID-19. Upaya pencegahan dengan melaksanakan protokol kesehatan terus digaungkan, tetapi angka kasus terkonfirmasi COVID-19 terus bertambah. Lonjakan kasus pun sempat terjadi beberapa kali di Indonesia yaitu pada bulan September 2020 dan Januari 2021 usai liburan panjang (Media Indonesia, 2021; Satuan Tugas Penanganan COVID-19, 2021a). Keadaan itu berakibat pada pelaksanaan kebijakan rem darurat di Jakarta melalui penerapan Pembatasan Sosial Berskala Besar (PSBB) karena peningkatan jumlah kasus yang sangat signifikan di wilayah tersebut (Pemprov DKI Jakarta, 2020).

Tepat satu tahun pandemi COVID-19, akumulasi jumlah kasus positif di Indonesia mencapai 1.403.722 (Satuan Tugas Penanganan COVID-19, 2021b). Untuk menurunkan angka kasus, selain melakukan protokol kesehatan maka perlu dilaksanakan upaya perlindungan khusus yaitu dengan vaksinasi. Selama bertahun-tahun vaksin terbukti dapat menurunkan kejadian penyakit menular melalui mekanisme imunitas tubuh manusia (Mortellaro \& RicciardiCastagnoli, 2011). Vaksin COVID-19 dikembangkan untuk membantu pembentukan imunitas tubuh individu sehinga pemberian vaksin COVID-19 tersebut diharapkan dapat mempercepat tebentuknya kekebalan kelompok (herd immunity) yang nantinya berdampak pada penurunan jumlah kasus yang terinfeksi (World Health Organization, 2020a).

Program vaksinasi COVID-19 di Indonesia dimulai pada tanggal 13 Januari 2021. Untuk gelombang pertama, vaksin tersebut diberikan ke tenaga kesehatan, petugas publik, dan lansia. Pada gelombang kedua, sasaran vaksinasi adalah masyarakat kelompok rentan dan masyarakat umum lainnya. Pemerintah menargetkan 181,5 juta orang sudah mendapatkan vaksinasi COVID-19 pada Maret 2022 (Kemenkes RI, 2021). Untuk memenuhi target yang telah ditetapkan, pemerintah Indonesia berusaha menjamin ketersediaan vaksin. Jenis vaksin yang telah dan akan digunakan di Indonesia adalah AstraZeneca, Moderna, Pfizer, Sinopharm dan 
Sinovac (Kemenkes RI, 2020a). Kelima jenis vaksin tersebut memiliki efikasi yang berbedabeda berdasarkan uji klinis yang telah dilakukan.

WHO memaparkan bahwa kinerja vaksin dapat dilihat dari tiga pengukuran yaitu melalui efikasi, efektivitas, dan dampak vaksin (World Health Organization, 2021b). Efikasi vaksin mengukur penurunan risiko infeksi yang terjadi pada individu yang divaksin dalam situasi terkontrol. Data efikasi ini diperoleh dari uji klinis secara acak (randomized control tria). Sedangkan efektivitas vaksin mengukur pengurangan risiko infeksi yang terjadi pada individu yang divaksin terkait dengan pelaksanaan vaksinasi di masyarakat atau dalam dunia nyata dengan menggunakan studi observasional. Selanjutnya dampak vaksin adalah pengurangan risiko infeksi atau penyakit pada populasi yang sebagian masyarakatnya sudah divaksin.

Studi yang menunjukkan efektivitas vaksin di beberapa negara sudah dilakukan (Amit et al., 2021; Dagan et al., 2021; Hall et al., 2021). Akan tetapi, belum tersedia data yang memperlihatkan bagaimana dampak vaksin tersebut di masyarakat Indonesia, terutama tekait dengan lima jenis vaksin yang digunakan. Studi yang mengukur dampak vaksin di populasi di lakukan di Inggris dengan menggunakan dua jenis vaksin yaitu AstraZeneca dan Pfizer (Pritchard et al., 2021).

Pemerintah Indonesia sampai April 2021 menargetkan 40,3 juta orang sudah tervaksin dengn dosis lengkap (dua kali dosis penyuntikan). Tiga jenis vaksin yaitu Sinovac, AstraZeneca dan Sinopharm sudah digunakan di Indonesia, tetapi pencapaian pemberian vaksin sampai akhir April 2021 hanya mencapai 19\% dari target (Satuan Tugas Penanganan COVID-19, 2021c). Selain kecepatan pemberian vaksin yang masih rendah, hal lain yang menyebabkan rendahnya cakupan vaksin COVID-19 adalah kurangnya penerimaan masyarakat terhadap vaksin itu sendiri. Harapan et al menemukan bahwa penerimaan vaksin akan lebih tinggi pada vaksin yang memiliki efikasi tinggi (Harapan et al., 2020). Di tahap pertama, jenis vaksin yang banyak digunakan adalah Sinovac yang dianggap memiliki efikasi yang rendah. Jika merujuk pada kinerja vaksin menurut WHO maka kita membutuhkan informasi bagaimana dampak vaksin tersebut pada tingkat masyarakat.

Salah satu upaya untuk memperoleh gambaran dampak vaksin di masyarakat adalah melalui pemodelan. Dalam kegiatan pengabdian mayarakat ini, pemodelan digunakan sebagai salah satu cara untuk memprediksi kondisi COVID-19 di Indonesia dengan kondisi yang dinamis, termasuk dengan bervariasinya jenis vaksin yang digunakan di Indonesia. Dengan demikian pemerintah dapat melakukan langkah-langkah strategis terkait program vaksinasi untuk menurunkan risiko penularan COVID-19 di masyarakat.

Pengabdian masyarakat ini bertujuan untuk memberi masukan bagi pemerintah dalam mengimplementasikan strategi vaksinasi COVID-19 dengan menyediakan analisis prediksi menggunakan pemodelan matematika dinamis untuk mengetahui efektifitas dan dampak vaksinasi pada tingkat masyarakat. Hasil pemodelan ini memberikan gambaran penurunan jumlah kasus COVID-19 dengan lima jenis vaksin yang sudah direncanakan penggunaanya di Indonesia. 


\section{Metode Pelaksanaan}

Kegiatan pengabdian masyarakat ini merupakan kelanjutan dari kegiatan sebelumnya yang sudah dipublikasikan (Joyosemito \& Nasir, 2021). Dengan demikian, tahapan pemodelannya merupakan pengembangan dari model COVID-19 sebelumnya. Pada pemodelan tersebut, Model COVID-19 disimulasikan untuk memproyeksikan kasus COVID-19 dengan kondisi ada atau tidaknya intervensi kebijakan dari pemerintah. Intervensi yang disimulasikan dalam penanganan COVID-19 pada pemodelan sebelumnya adalah Pembatasan Sosial Skala Besar (skenario PSBB) dan New Normal atau PSBB transisi (skenario PSBB Diperlonggar). Untuk pemodelan dalam kegiatan pengabdian masyarakat saat ini, intervensi kebijakan pemerintah yang disimulasikan dalam penanganan COVID-19 adalah program vaksinasi COVID-19 kepada masyarakat.

Tahap analisis data dan pengembangan model dilakukan dengan langkah berikut: a) Mengumpulkan dan menganalisis data kasus COVID-19 di Indonesia terkait kasus konfirmasi positif, kematian dan kesembuhan yang bersumber dari laman covid19.go.id.; b) Membangun model dengan dua skenario dasar yaitu BAU yang memproyeksikan kasus COVID-19 di Indonesia sesuai kondisi yang sedang berjalan tanpa adanya intervensi kebijakan vaksinasi dan VAKSIN yang memproyeksikan kasus COVID-19 di Indonesia dengan intervensi kebijakan vaksinasi dengan menggunakan lima jenis vaksin. Jenis vaksin dan efikasinya dalam pemodelan ini ditunjukkan dalam table 1; c) Lima jenis vaksin yang dimasukkan dalam perhitungan model ini memiliki dosis penyuntikan masing-masing dua kali dengan interval waktu pemberian yang berbeda-beda (Kemenkes RI, 2020b). Akan tetapi, pemodelan dalam kegiatan pengabdian masyarakat ini menggunakan interval waktu rata-rata 14 hari karena saat model ini dibuat, vaksin yang sudah digunakan di masyarakat dan sebagian besar akan digunakan pada tahap pertama adalah Sinovac (Sekretariat Kabinet Republik Indonesia, 2021). Selain itu, interval waktu pemberian vaksin juga masih terus berkembang diantara jenis vaksin seperti dipaparkan pada beberapa studi yang terus berlangsung (Kriss et al., 2021; Nam et al., 2021; Wise, 2021).

Tabel 1. Efikasi Jenis Vaksin

\begin{tabular}{lcl}
\hline \multicolumn{1}{c}{ Jenis Vaksin } & Efikasi & \multicolumn{1}{c}{ Keterangan/Rujukan } \\
\hline AstraZeneca & $62,1 \%$ & (Mahase, 2020) \\
\hline Moderna & $94,1 \%$ & (Baden et al., 2021) \\
\hline Pfizer & $95 \%$ & (Polack et al., 2020) \\
\hline Sinopharm & $79,34 \%$ & (Kyriakidis et al., 2021) \\
\hline Sinovac & $65,3 \%$ & (World Health Organization et al., 2021)
\end{tabular}

Sumber: Hasil Pelaksanaan (2021)

d) Pencapaian pemberian vaksin kepada masyarakat sampai saat model diformalkan dan dirunning dijadikan sebagai data input untuk kecepatan rata-rata vaksinasi per hari pada periode 13 Januari - 9 Maret 2021, yaitu antara 50.056 - 71.050 dosis/hari yang disimulasikan secara random. Data input tersebut mulai diterapkan ke dalam model per tanggal 13 Januari 
2021, waktu ini merupakan mulai dilaksanakannya kebijakan program vaksinasi di Indonesia (Kompas.com, 2021); e) Model COVID-19 dikembangkan dengan menggunakan konsep matematika dinamis dengan dasar persamaan integral (P.1) dan turunan (P.2) seperti yang sudah dijelaskan pada publikasi sebelumnya. Persamaan dari matematika dinamis dibangun/dirangkai berdasarkan struktur hubungan keterkaitan antar variabel utama di sistem nyata terkait program vaksinasi COVID-19 yang ditunjukkan oleh Gambar 1.

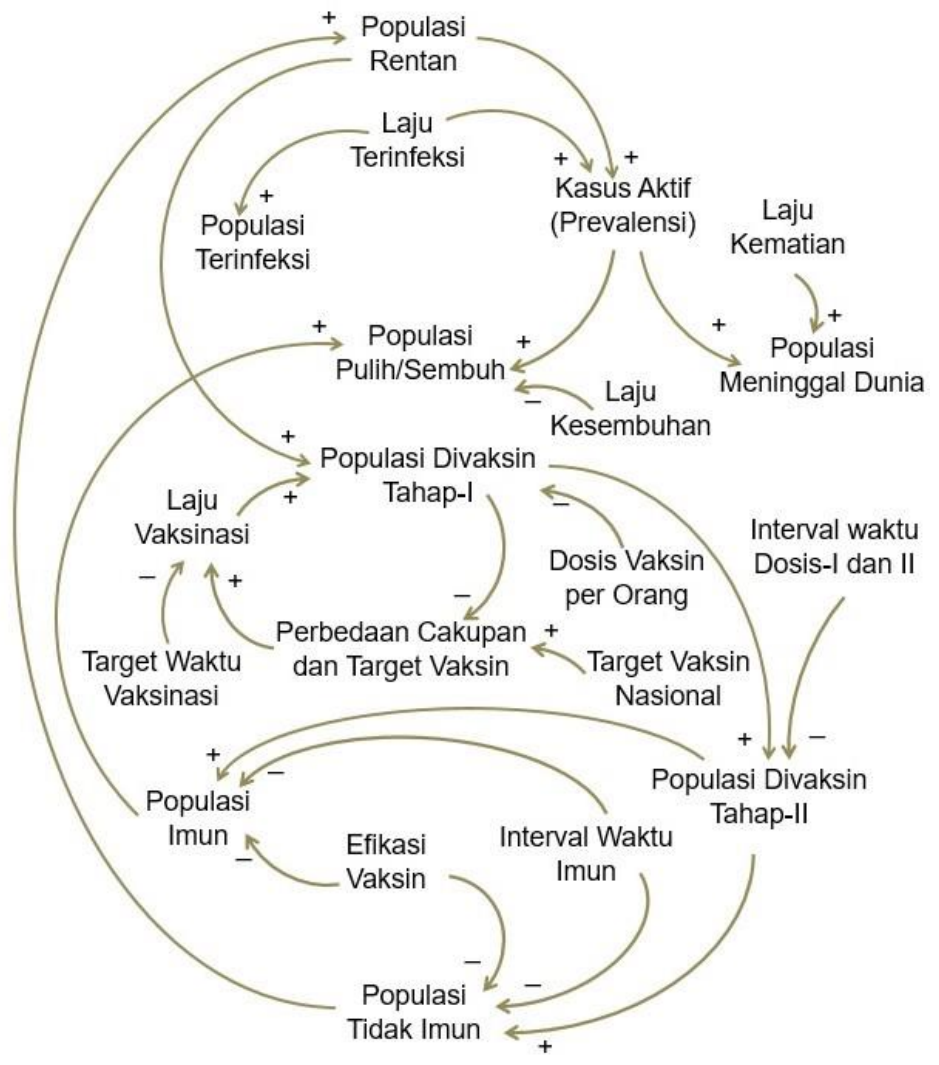

Sumber: Hasil Pelaksanaan (2021)

Gambar 1. Struktur Hubungan Antar Variable Inti Untuk Model COVID-19 Vaksin

f) Model COVID-19 disimulasikan untuk periode Maret 2020 hingga Desember 2021 dengan step time 1 hari. Waktu simulasi ini untuk mengambarkan data historis sejak kasus COVID-19 ditemukan (di awal Maret 2020) dan data estimasi dari model setelah implementasi kebijakan vaksinasi.

Sama dengan sebelumnya, model ini diformalkan dengan menggunakan software Analytica Educational Professional dan disimulasikan secara bersamaan dengan metode sampling Simple Monte Carlo dengan 1000 sampel acak sehingga hasil keluaran dari model adalah nilai/angka ketidakpastian (uncertainty value) yang direpresentasikan dengan angka maksimum (max), rata-rata (mean) dan minimum (min).

\section{Hasil dan Pembahasan}

Kegiatan pengabdian masyarakat untuk memasukkan intervensi kebijakan vaksinasi COVID-19 ke dalam pemodelan ini merupakan permintaan dari pihak pemerintah dalam hal ini 
Menteri Koordinator Bidang Pembangunan Manusia dan Kebudayaan pada Rapat via Video Conference (Zoom Meeting), pada Selasa, 2 Oktober 2020:

"Semua pemodeling kok tidak menghitung datangnya Vaksin, intervensi masuknya vaksin itu kan akan menjadi variabel determinan yang akan menentukan prediksi maupun proyeksi dari perkembangan covid di Indonesia" (M. Effendy, Video Conference, 2020).

Pada rapat lanjutan via Video Conference (Zoom Meeting), Rabu, 7 Oktober 2020, Dirjen Pencegahan dan Pengendalian Penyakit Kementerian Kesehatan turut hadir untuk memaparkan perencanaan program vaksinasi nasional COVID-19 kepada para pemodeling guna memberikan informasi atau gambaran tentang kebijakan dan langkah-langkah yang akan diimplementasikan (di sistem nyata) yang nanti dapat diterjemahkan oleh masing-masing pemodel dalam bahasa pemodelan.
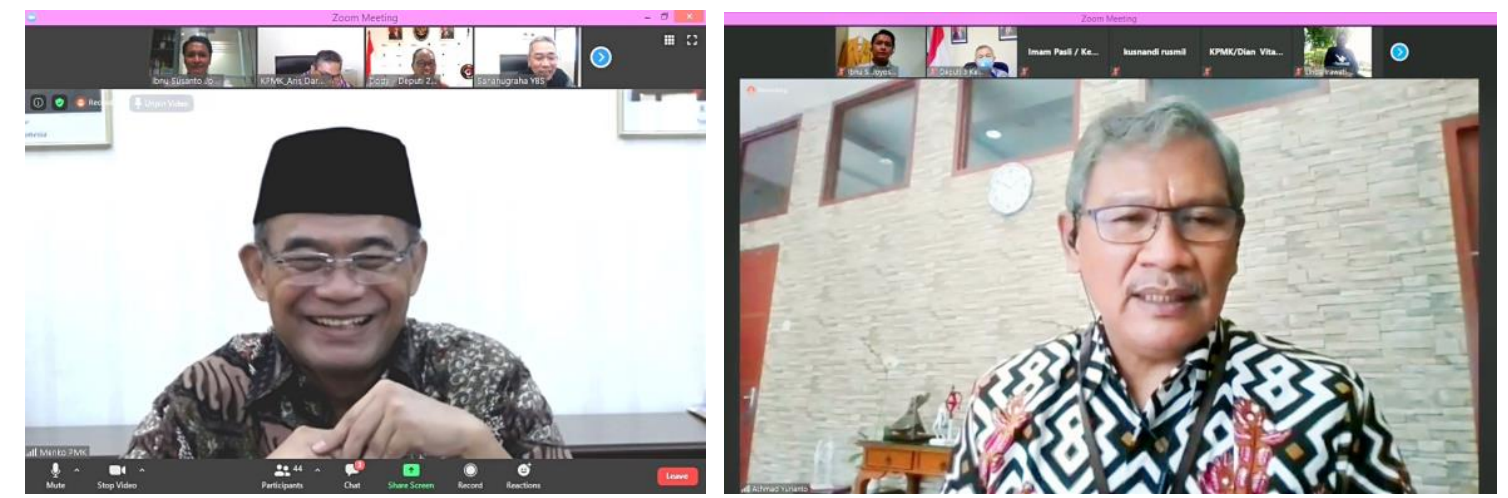

Sumber: Hasil Pelaksanaan (2020)

Gambar 2. Rapat Dengan Pemerintah Via Video Conference (Zoom Meeting)

Pada gambar 2 rapat dengan pemerintah dilaksanakan pada Selasa, 2 Oktober 2020 Pukul 09.00 dengan agenda: Perkembangan Hasil Analisa Pemodelan Covid-19 di Indonesia (kiri gambar) dan pada Rabu, 7 Oktober 2020 Pukul 10.00 dengan agenda: Strategi Intervensi Penanganan Pandemi Covid-19 (kanan gambar).

Hasil keluaran dari model COVID-19 menunjukkan bahwa jika program vaksiniasi kepada masyarakat terus dilaksanakan secara konsisten sejak tanggal 13 Januari 2021 sampai akhir desember 2021 dengan keceparan rata-rata 50.056 - 71.050 dosis/hari maka akan terjadi penurunan kasus positif (lihat Gambar 3 sisi kiri) sehingga jumlah kasus aktif kesembuhan dan kematian pun ikut menurun. Gambar 3 menunjukan terjadi kumulatif kasus positif di bawah skenario BAU yang diperkirakan akan berada di rentang 3,505 juta (max), 3,442 juta (mean) dan 3,389 juta (min) di akhir Desember 2021. Selanjutnya, di bawah skenario VAKSIN, penurunan kasus positif antar jenis vaksin yang digunakan terlihat tidak jauh berbeda apabila dibandingkan dengan skenario BAU. Kumulatif kasus positif di akhir Desember 2021 apabila menggunakan vaksin jenis Sinovac diperkirakan akan berada di angka mean: 2,846 juta. Apabila menggunakan vaksin AstraZeneca, Moderna, Pfizer, dan Sinopharm maka masingmasing berada di angka mean: 2,848 juta, 2,835 juta, 2,834 juta dan 2,841 juta.

Hasil keluaran model COVID-19 untuk kumulatif kasus aktif atau prevalensi yaitu kasus positif setelah dikurangi penderita yang sembuh dan meninggal dunia yang sedang berjalan, 
ditunjukkan pada Gambar 3 sisi kanan. Di bawah skenario BAU, kumulatif kasus aktif pada akhir bulan Desember 2021 diperkirakan berada di rentang 124.040 (max), 112.727 (mean) dan 101.649 (min). Untuk kumulatif kasus aktif di bawah skenario VAKSIN yang ditunjukkan oleh Gambar 4 (warna Biru) merupakan gabungan dari kelima jenis vaksin yang disimulasikan yaitu sesuai angka max yang paling tinggi dan angka min yang paling rendah dari kelimanya, sedangkan untuk angka mean menggunakan vaksin Sinovac. Jadi di bawah skenario VAKSIN, kumulatif kasus aktif pada akhir bulan Desember 2021 diperkirakan berada di rentang 63.165 (max, dengan jenis vaksin AstraZeneca), 56387 (mean, dengan jenis vaksin Sinovac) dan 50288 (min dengan jenis vaksin Pfizer).
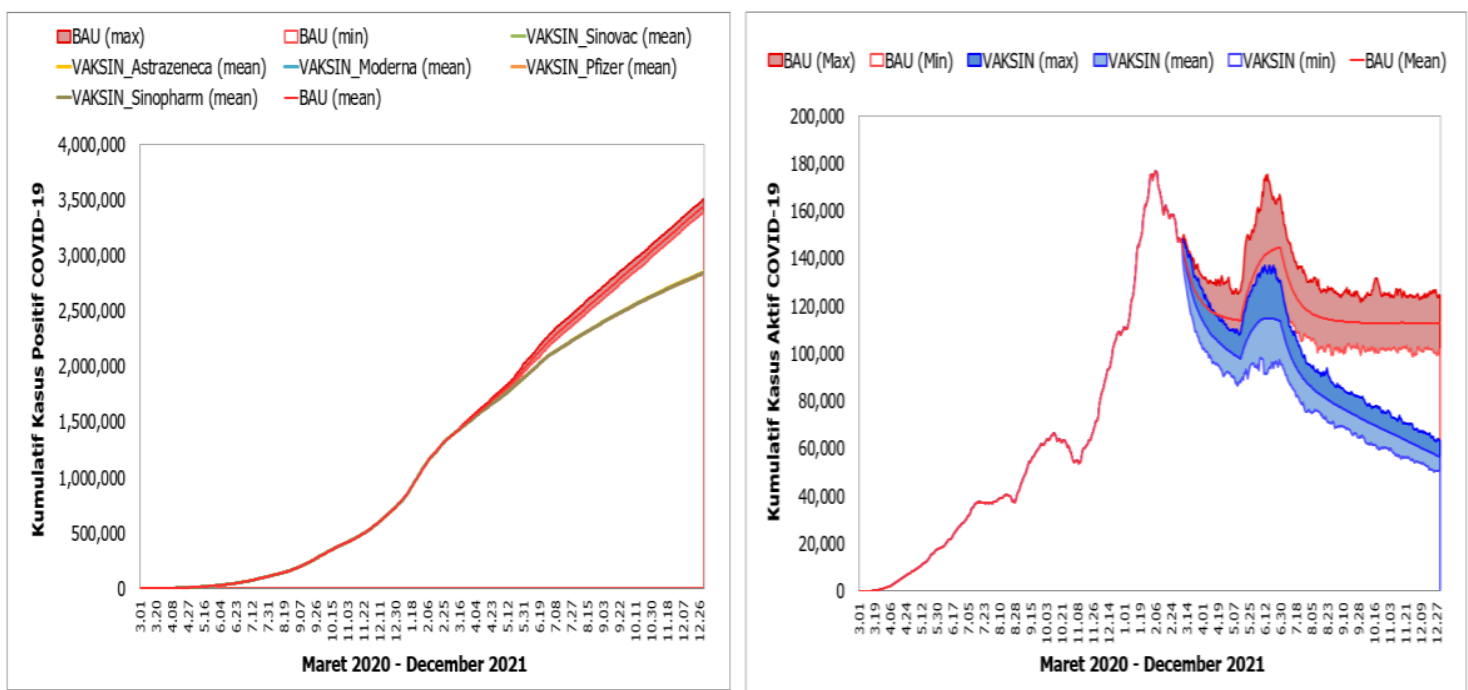

Sumber: Hasil Pelaksanaan (2021)

Gambar 3. Hasil Keluaran Model COVID-19 Untuk Kumulatif Kasus Positif dan Aktif

Perbadingan antara skenario BAU dan VAKSIN menunjukkan adanya penurunan jumlah kasus aktif COVID-19 yang signifikan antara adanya dan tanpa adanya kebijakan program vaksinasi. Dengan menggunakan perbandingan angka mean maka pada akhir bulan Desember 2021 kasus aktif menurunan hingga 49,98\% apabila menggunakan vaksin Sinovac. Selanjutnya, jika menggunakan vaksin AstraZeneca, Moderna, Pfizer, dan Sinopharm maka masing-masing penurunannya adalah 49,87\%, 50,99\%, 51,02\%, dan 50,47\%. Tabel 2. menyajikan besar penurunan kasus aktif dari intervensi kebijakan program vaksinasi berdasarkan perbandingan skenario BAU dan VAKSIN dalam rentang angka max, mean dan min. Hasil keluaran model pada Tabel 2 menggambarkan bahwa besaran penurunan kasus aktif COVID-19 antar jenis vaksin dapat dikatakan sebanding dengan efikasinya (lihat Tabel 1. untuk efikasi vaksin), akan tetapi tidak ditemukan perbedaan yang besar dalam hal penurunannya terkait dengan penggunaan jenis vaksin yang berbeda. Misal untuk Pfizer (efikasi: 95\%) versus Sinovac (efikasi: $65,3 \%$ ) terlihat bahwa jenis vaksin yang memiliki efikasi lebih tinggi memang menurunkan kasus aktif lebih tinggi dari jenis vaksin yang efikasinya lebih rendah, tetapi di sisi lainnya, perbedaan penurunannya tersebut tidak besar antar jenis vaksin (lihat Table 2., untuk angka mean: Pfizer menurunkan 51,02\% sedangkan Sinovac 49,98\%). 
Dalam hal ini model mendemonstrasikan bahwa efektivitas vaksin setelah diimunisasikan ke masyarakat dipengaruhi oleh efikasinya, tetapi efikasi antar jenis vaksin tidak terlalu berpengaruh terhadap dampak vaksin di masyarakat. Dampak vaksin yang tidak terlalu signifikan tersebut dapat terjadi karena cakupan vaksin (jumlah populasi yang telah mendapatkan vaksinasi) yang masih rendah, masih jauh dari target.

Tabel 2. Penurunan Kasus Aktif COVID-19 Berdasarkan Jenis Vaksin yang Digunakan

\begin{tabular}{llcc}
\hline \multirow{2}{*}{ Jenis Vaksin } & \multicolumn{3}{c}{ Penurunan Kasus Aktif COVID-19 } \\
\cline { 2 - 4 } & Maksimum & Mean & Minimum \\
\hline AstraZeneca & $49,65 \%$ & $49,47 \%$ & $49,48 \%$ \\
\hline Moderna & $50,76 \%$ & $50,99 \%$ & $50,59 \%$ \\
\hline Pfizer & $50,79 \%$ & $51,02 \%$ & $50,62 \%$ \\
\hline Sinopharm & $50,25 \%$ & $50,47 \%$ & $50,06 \%$ \\
\hline Sinovac & $49,76 \%$ & $49,98 \%$ & $49,59 \%$ \\
\hline
\end{tabular}

Sumber: Hasil Pelaksanaan (2021)

Studi pada populasi yang terkait efektivitas vaksin telah dilakukan di Inggris dan Israel. Menurut studi tersebut, di Inggris ditemukan bahwa efektivitas Pfizer adalah 85\%, berbeda dari efikasinya berdasarkan uji klinis yaitu 95\% (Hall et al., 2021). Sementara itu, studi di Israel yang telah melakukan vaksinasi masal menemukan bahwa efektivitas Pfizer adalah 92\% (Dagan et al., 2021). Menurut WHO (2021b), pengukuran kinerja vaksin tidak hanya dilihat dari efikasi ataupun efektivitasnya, tetapi juga melalui dampak vaksin. Pengukuran dampak vaksin itu sangat tergantung pada cakupan vaksin dan efek dari mereka yang divaksin ataupun tidak, khususnya terkait dengan perlindungan masyarakat (herd protection). Dampak vaksin juga berhubungan dengan hal lainnya seperti fungsi dan kapasitas sistem kesehatan dan indikator ekonomi. Oleh karena itu, dampak vaksin di tingkat masyarakat bisa berbeda dari efikasi maupun efektivitasnya mengingat permasalahan di masyarakat yang cukup kompleks. Berdasarkan pengetahuan penulis, hingga saat ini studi yang membahas dampak vaksin di tingkat masyarakat dengan menggunakan jenis vaksin yang berbeda-beda sangat terbatas. Hal ini dapat dipahami mengingat kompleksitas studi yang harus dilakukan untuk mengukur dampak vaksin tersebut yang dianggap tidak praktis, tidak etis, kontraproduktif, dan tidak cocok secara politis (World Health Organization, 2021b).

Penurunan kasus aktif dari program vaksinasi tersebut belum bisa dikatakan mencapai level aman walaupun secara umum dapat dilihat kurva kasus terus melandai sampai akhir bulan Desember 2021. Berdasarkan catatan kejadian sebelumnya, libur panjang akan menjadi pemicu melonjaknya kasus (Media Indonesia, 2021). Model juga memperkirakan akan terjadi lagi hal yang sama yaitu pada saat pasca hari besar nasional Idul fitri (lihat gambar 4., puncak kurva/gelombang kedua dari sisi kiri. Pada saat itu pertambahan kasus positif harian diprediksi akan mencapai 15.740 per hari (max), 8.485 per hari (mean) dan 1.497 per hari (min) untuk skenario BAU, sedangkan untuk skenario VAKSIN, 12.347 per hari (max), 6.636 per hari (mean) dan 1.162 per hari (min). Lonjakan kasus tersebut dapat diakibatkan karena abainya 
masyarakat terhadap protokol kesehatan termasuk tidak mematuhi larangan untuk mengurangi mobilitas (Satuan Tugas Penanganan COVID-19, 2021c). Padahal, studi yang dilakukan oleh Nouvellet et al menegaskan bahwa pengurangan mobilitas akan menurunkan transmisi COVID19 (Nouvellet et al., 2021).

Pengurangan risiko dan transmisi COVID-19 tersebut dapat diturunkan jika terbentuk herd immunity yang dapat dicapai melalui kebijakan vaksinasi. Jika seseorang memiliki imunitas terhadap COVID-19 maka secara tidak langsung ia akan melindungi individu lain yang tidak memiliki imunitas. Batasan herd immunity sangat bergantung pada seberapa menular penyakitnya. Dalam hal COVID-19, herd immunity yang disarankan adalah 70\% (D'Souza, 2021). Untuk mencapai $70 \%$ herd immunity tidaklah mudah, selama level tersebut belum terpenuhi, risiko terinfeksi COVID-19 tetap tinggi. Oleh karena itu, diperlukan upaya percepatan penyuntikan vaksin per hari dengan menjamin ketersediaan vaksin sehingga target 181,5 juta penduduk Indonesia tervaksin bisa tercapai. Berdasarkan pemodelan yang telah dibuat, program vaksinasi merupakan cara yang efektif untuk menurunkan jumlah kasus. Akan tetapi perlu diingat bahwa intervensi yang dilakukan untuk menurunkan kasus COVID-19 tidak cukup hanya dengan vaksin. Tidak ada satupun vaksin yang memiliki efektivitas sampai $100 \%$ (Immunisation Advisory Center, 2020). Oleh karena itu dalam kasus COVID-19, meskipun vaksinasi sudah dilakukan, protokol kesehatan tetap harus dijalankan seperti memakai masker, menjaga jarak, mencuci tangan dan menghindari kerumunan, dan mengurangi mobilitas (Silberner, 2021; World Health Organization, 2021c)

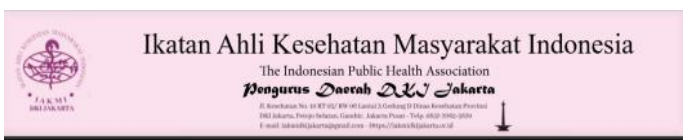

SIARAN PERS IKATAN AHL KESEHATAN MASYARAKAT (AKKM) DKI JAKARTA SATU TAHIN PANDEMI;
SAATNYA MOBILSASI AKAR RLMPUT DAAM PERCPATAN VAKSINASI SERTA
MEMPERKETAT PROTOKOL KESEHATAN

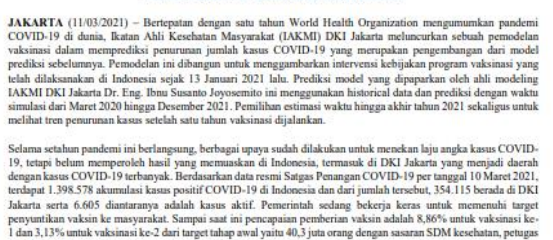

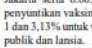

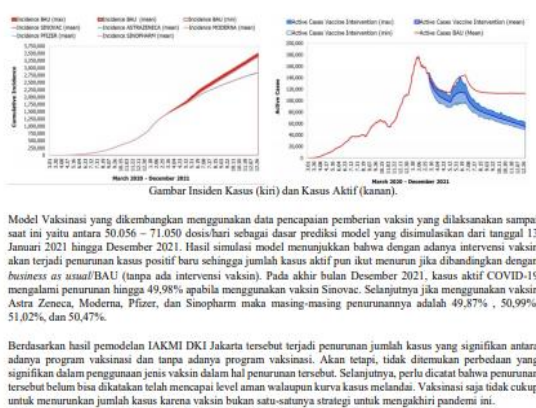

Prace 1 of

Sumber: Hasil Pelaksanaan (2021)

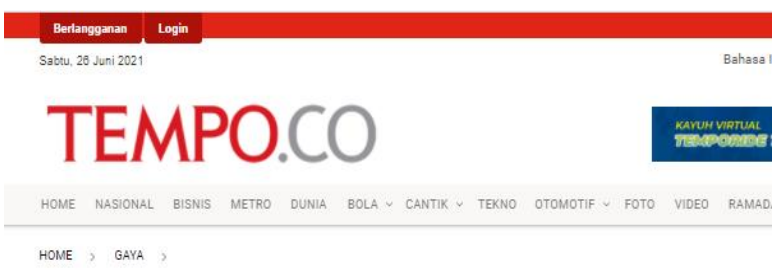

Setahun Pandemi Covid-19, Cek Seberapa Efektif Vaksinasi Menekan Kasus Covid-19

Reporter: Tempo.co

Kamis, 11 Maret 202116.20 WB

KOMESTAR

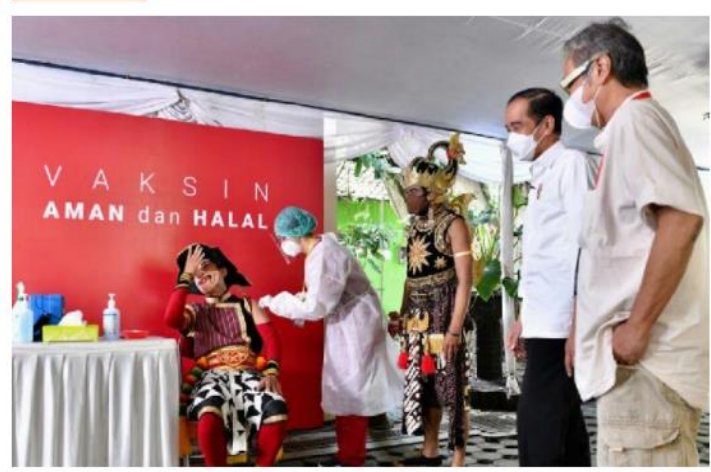

Gambar 5. Diseminasi Berupa Siaran Pers 
Diseminasi berupa siaran pers yang dikeluarkan oleh IAKMI pada 11 Maret 2021 dengan judul: Satu Tahun Pandemi: Saatnya Mobilisasi Akar Rumput Dalam Percepatan Vaksinasi Serta Memperketat Protokol Kesehatan (kiri gambar) dan publikasi di Surat Kabar yaitu Koran Tempo yang terbit pada 11 Maret 2021 dengan judul: Setahun Pandemi COVID-19, Cek Seberapa Efektif Vaksinasi Menekan Kasus Covid-19 (kanan gambar).

Hasil keluaran Model COVID-19 VAKSIN tersebut didiseminasikan kepada masyarakat bertepatan dengan satu tahun pandemi COVID-19 setelah WHO menyatakan COVID-19 sebagai pandemi (World Health Organization, 2020b). Diseminasi dilakukan melalui melalui Siaran Pers yang dikeluarkan oleh Ikatan Ahli Kesehatan Masyarakat (IAKMI) pada tanggal 11 Maret 2021 dengan judul: Satu Tahun Pandemi: Saatnya Mobilisasi Akar Rumput Dalam Percepatan Vaksinasi Serta Memperketat Protokol Kesehatan (Gambar 5.) dan melalui Media Massa Tempo yang terbit pada 11 Maret 2021 dengan judul: Setahun Pandemi COVID-19, Cek Seberapa Efektif Vaksinasi Menekan Kasus COVID-19.

\section{Kesimpulan}

Kebijakan vaksinasi memberikan dampak dalam penurunan jumlah kasus COVID-19 yang masih belum terkendali di Indonesia. Hasil keluaran model menunjukkan dampak vaksin di tingkat masyarakat tidak terlalu signifikan perbedaannya antar jenis vaksin yang berbeda efikasinya. Langkah strategis yang harus dilakukan pemerintah adalah menjamin ketersediaan vaksin apa pun jenisnya, mengakselerasi proses vaksinasi ke masyarakat dengan meningkatkan manajemen pelayanan vaksinasi sehingga target yang sudah ditetapkan tercapai dan mendorong partisipasi masyarakat untuk divaksin agar terbentuk herd immunity. Selanjutnya, mengingat bahwa dampak vaksin di masyarakat bukan hanya ditentukan oleh efikasinya, maka pemerintah harus terus melakukan upaya edukasi dan mendorong pelibatan masyarakat secara aktif untuk patuh menerapkan protokol kesehatan COVID-19. Model COVID-19 ini masih terus dikembangkan dan diperbaharui, analisis model sampai tahap pengembangan saat ini telah mampu memberikan gambaran dan pemahaman baru khususnya terkait studi dampak vaksin di masyarakat yang apabila dilakukan pada sistem nyata akan lebih sulit dilakukan.

\section{Ucapan Terima Kasih}

Terimakasih kepada Ketua PP Ikatan Ahli Kesehatan Masyarakat Indonesia (IAKMI) Dr. Ede Darmawan, S.K.M., MDM atas dukungannya dalam kegiatan ini. Penulis mengucapkan terimakasih kepada Menteri Koordinator Bidang PMK Prof. Dr. Muhajjir Effendy, M.A.P. yang telah memberikan kesempatan bagi penulis untuk berkontribusi memberi masukan terkait kebijakan penanganan COVID-19 di Indonesia melalui Keputusan Menteri Koordinator Bidang PMK No.9 Tahun 2020. 


\section{Daftar Pustaka}

Amit, S., Regev-Yochay, G., Afek, A., Kreiss, Y., \& Leshem, E. (2021). Early rate reductions of SARS-CoV-2 infection and COVID-19 in BNT162b2 vaccine recipients. The Lancet, 397(10277), 875-877. https://doi.org/10.1016/S0140-6736(21)00448-7

Baden, L. R., El Sahly, H. M., Essink, B., Kotloff, K., Frey, S., Novak, R., Diemert, D., Spector, S. A., Rouphael, N., Creech, C. B., McGettigan, J., Khetan, S., Segall, N., Solis, J., Brosz, A., Fierro, C., Schwartz, H., Neuzil, K., Corey, L., ... Zaks, T. (2021). Efficacy and Safety of the mRNA-1273 SARS-CoV-2 Vaccine. New England Journal of Medicine, 384(5), 403416. https://doi.org/10.1056/nejmoa2035389

D'Souza, G. (2021). What is Herd Immunity and How Can We Achieve It With COVID-19? Stopping SARS-CoV-2 will require a substantial percentage of the. https://www.jhsph.edu/covid-19/articles/achieving-herd-immunity-with-covid19.html

Dagan, N., Barda, N., Kepten, E., Miron, O., Perchik, S., Katz, M. A., Hernán, M. A., Lipsitch, M., Reis, B., \& Balicer, R. D. (2021). BNT162b2 mRNA Covid-19 Vaccine in a Nationwide Mass Vaccination Setting. New England Journal of Medicine, 384(15), 1412-1423. https://doi.org/10.1056/nejmoa2101765

Hall, V. J., Foulkes, S., Saei, A., Andrews, N., Oguti, B., Charlett, A., Wellington, E., Stowe, J., Gillson, N., Atti, A., Islam, J., Karagiannis, I., Munro, K., Khawam, J., Chand, M. A., Brown, C. S., Ramsay, M., Lopez-Bernal, J., Hopkins, S., ... Heeney, J. L. (2021). COVID-19 vaccine coverage in health-care workers in England and effectiveness of BNT162b2 mRNA vaccine against infection (SIREN): a prospective, multicentre, cohort study. The Lancet, 397(10286), 1725-1735. https://doi.org/10.1016/S0140-6736(21)00790-X

Harapan, H., Wagner, A. L., Yufika, A., Winardi, W., Anwar, S., Gan, A. K., Setiawan, A. M., Rajamoorthy, Y., Sofyan, H., \& Mudatsir, M. (2020). Acceptance of a COVID-19 Vaccine in Southeast Asia: A Cross-Sectional Study in Indonesia. Frontiers in Public Health, 8(July), 1-8. https://doi.org/10.3389/fpubh.2020.00381

Immunisation Advisory Center. (2020). Efficacy and effectiveness. https://doi.org/10.1177/0969141321995223

Joyosemito, I. S., \& Nasir, N. M. (2021). Pendekatan Pemodelan Matematika Dinamis Dalam Analisis Prediksi COVID-19 Sebagai Masukan Kebijakan Pemerintah Indonesia. Jurnal $\begin{array}{llll}\text { Abdimas } & \text { UBJ } & \text { 1-16. }\end{array}$ http://ejurnal.ubharajaya.ac.id/index.php/Jabdimas/article/view/455

Kemenkes RI. (2020a). Keputusan Menteri Kesehatan Republik Indonesia Nomor Hk.01.07/Menkes/12757/2020 Tentang Penetapan Sasaran Pelaksanaan Vaksinasi Corona Virus Disease 2019 (Covid-19). In Keputusan Menteri Kesehatan Republik Indonesia Nomor Hk.01.07/Menkes/12757/2020 Tentang Penetapan Sasaran Pelaksanaan Vaksinasi Corona Virus Disease 2019 (Covid-19).

Kemenkes RI. (2020b). Frequently Asked Question Seputar Pelaksanaan Vaksinasi COVID-19. https://kesmas.kemkes.go.id/assets/uploads/contents/others/FAQ_VAKSINASI_COVID_ 
call_center.pdf

Kemenkes RI. (2021). Pelaksanaan Vaksinasi COVID-19 di Indonesia Membutuhkan Waktu 15 Bulan - Sehat Negeriku. https://sehatnegeriku.kemkes.go.id/baca/rilismedia/20210103/2536122/pelaksanaan-vaksinasi-covid-19-indonesia-membutuhkanwaktu-15-bulan/

Kompas.com. (2021). Jokowi Disuntik Vaksin Pertama Ini Cara Kerja Vaksin Sinovac Cegah Covid-19. 13 Januari, 1-9. https://www.kompas.com/tren/read/2021/01/13/134500065/jokowi-disuntik-vaksinpertama-ini-cara-kerja-vaksin-sinovac-cegah-covid-19?page=all

Kriss, J. L., Reynolds, L. E., Wang, A., Stokley, S., Cole, M. M., Harris, L. T. Q., Shaw, L. K., Black, C. L., Singleton, J. A., Fitter, D. L., Rose, D. A., Ritchey, M. D., \& Toblin, R. L. (2021). COVID-19 Vaccine Second-Dose Completion and Interval Between First and Second Doses Among Vaccinated Persons — United States, December 14,2020-February 14, 2021. In MMWR Recommendations and Reports (Vol. 70, Issue 11). https://doi.org/10.15585/mmwr.mm7011e2

Kyriakidis, N. C., López-Cortés, A., González, E. V., Grimaldos, A. B., \& Prado, E. O. (2021). SARS-CoV-2 vaccines strategies: a comprehensive review of phase 3 candidates. Npj Vaccines, 6(1). https://doi.org/10.1038/s41541-021-00292-w

Mahase, E. (2020). Covid-19: UK government asks regulator to assess Oxford vaccine as questions are raised over interim data. BMJ (Clinical Research Ed.), 371(December), m4670. https://doi.org/10.1136/bmj.m4670

Media Indonesia. (2021). Antisipasi Lonjakan Kasus. https://mediaindonesia.com/editorials/detail_editorials/2331-antisipasi-lonjakan-kasus

Mortellaro, A., \& Ricciardi-Castagnoli, P. (2011). From vaccine practice to vaccine science: The contribution of human immunology to the prevention of infectious disease. Immunology and Cell Biology, 89(3), 332-339. https://doi.org/10.1038/icb.2010.152

Nam, A., Ximenes, R., Yeung, M. W., Mishra, S., Wu, J., Tunis, M., \& Sander, B. (2021). Modelling the impact of extending dose intervals for COVID-19 vaccines in Canada. MedRxiv. https://www.medrxiv.org/content/10.1101/2021.04.07.21255094v1

Nouvellet, P., Bhatia, S., Cori, A., Ainslie, K. E. C., Baguelin, M., Bhatt, S., Boonyasiri, A., Brazeau, N. F., Cattarino, L., Cooper, L. V., Coupland, H., Cucunuba, Z. M., CuomoDannenburg, G., Dighe, A., Djaafara, B. A., Dorigatti, I., Eales, O. D., van Elsland, S. L., Nascimento, F. F., ... Donnelly, C. A. (2021). Reduction in mobility and COVID-19 transmission. Nature Communications, 12(1), 1-9. https://doi.org/10.1038/s41467-02121358-2

Pemprov DKI Jakarta. (2020). Kebijakan Rem Darurat, Pemprov DKI Jakarta Tetapkan Kembali Pembatasan Sosial Berskala Besar (Siaran Pers 9 September 2021).

Polack, F. P., Thomas, S. J., Kitchin, N., Absalon, J., Gurtman, A., Lockhart, S., Perez, J. L., Pérez Marc, G., Moreira, E. D., Zerbini, C., Bailey, R., Swanson, K. A., Roychoudhury, S., 
Koury, K., Li, P., Kalina, W. V., Cooper, D., Frenck, R. W., Hammitt, L. L., ... Gruber, W. C. (2020). Safety and Efficacy of the BNT162b2 mRNA Covid-19 Vaccine. New England Journal of Medicine, 383(27), 2603-2615. https://doi.org/10.1056/nejmoa2034577

Pritchard, E., Matthews, P. C., Stoesser, N., Eyre, D. W., Gethings, O., Vihta, K.-D., Jones, J., House, T., Vansteenhouse, H., Bell, I., Bell, J. I., Newton, J. N., Farrar, J., Diamond, I., Rourke, E., Studley, R., Crook, D., Peto, T., Walker\#, A. S., \& Pouwels\#, K. B. (2021). Impact of vaccination on SARS-CoV-2 cases in the community: a population-based study using the UK's COVID-19 Infection Survey. MedRxiv. https://doi.org/10.1101/2021.04.22.21255913

Satuan Tugas Penanganan COVID-19. (2021a). Lonjakan Kasus Dampak Abaikan Protokol Kesehatan. https://covid19.go.id/p/berita/lonjakan-kasus-dampak-abaikan-protokolkesehatan

Satuan Tugas Penanganan COVID-19. (2021b). Data Vaksinasi COVID-19 (Update per 11 Maret 2021 ). https://covid19.go.id/p/berita/data-vaksinasi-covid-19-update-11-maret-2021 Satuan Tugas Penanganan COVID-19. (2021c). Berita Terkini Data Vaksinasi COVID-19 ( Update per 1 Mei 2021 ). https://covid19.go.id/p/berita/data-vaksinasi-covid-19-update-1mei-2021

Sekretariat Kabinet Republik Indonesia. (2021). Vaksinasi Segera Dimulai, Presiden: 329,5 Juta Dosis Vaksin COVID-19 Telah Dipesan. https://setkab.go.id/vaksinasi-segera-dimulaipresiden-3295-juta-dosis-vaksin-covid-19-telah-dipesan/

Silberner, J. (2021). Why You Should Still Wear A Mask And Avoid Crowds After Getting The COVID-19 Vaccine. Npr. https://www.npr.org/sections/healthshots/2021/01/12/956051995/why-you-should-still-wear-a-mask-and-avoid-crowds-aftergetting-the-covid-19-vac

Wise, J. (2021). CoviD-19: New data on oxford AstraZeneca vaccine backs 12 week dosing interval. The BMJ, 372(February), 2021. https://doi.org/10.1136/bmj.n326

World Health Organization. (2020a). Tanya Jawab: Lockdown dan herd immunity. https://www.who.int/indonesia/news/novel-coronavirus/qa/qa-lockdown-and-herd-immunity

World Health Organization. (2020b). Archived: WHO Timeline - COVID-19. Wold Health Organization. https://www.who.int/news-room/detail/27-04-2020-who-timeline---covid-19

World Health Organization. (2021a). Global Situation March 11, 2021. https://covid19.who.int

World Health Organization. (2021b). Evaluation of COVID-19 vaccine effectiveness. https://www.who.int/publications/i/item/WHO-2019-nCoV-vaccine_effectivenessmeasurement-2021.1

World Health Organization. (2021c). COVID-19 advice for the public: Getting vaccinated. In $\begin{array}{llll}\text { Coronavirus disease (COVID-19) June). } & \text { (Issue }\end{array}$ https://www.who.int/emergencies/diseases/novel-coronavirus-2019/covid-19vaccines/advice 
World Health Organization, e Strategic Advisory Group of Experts on Immunization (SAGE), SAGE Working Group, \& on COVID-19 Vaccines. (2021). Interim recommendations for use of the inactivated COVID-19 vaccine, CoronaVac, developed by Sinovac (Issue May). https://apps.who.int/iris/bitstream/handle/10665/338484/WHO-2019-nCoV-vaccinesSAGE_recommendation-BNT162b2-2021.1-eng.pdf? sequence $=1$ \&isAllowed=y 